\title{
PhyA, a Secreted Protein of Xanthomonas oryzae pv. oryzae, Is Required for Optimum Virulence and Growth on Phytic Acid as a Sole Phosphate Source
}

\author{
Subhadeep Chatterjee, Rajan Sankaranarayanan, and Ramesh V. Sonti \\ Centre for Cellular and Molecular Biology, Uppal Road, Hyderabad-500 007, India \\ Submitted 10 April 2003. Accepted 1 July 2003.
}

\begin{abstract}
Xanthomonas oryzae pv. oryzae causes bacterial leaf blight, a serious disease of rice. We have identified a novel virulence deficient mutant (BXO1691) of $X$. oryzae pv. oryzae that has a $\mathbf{T n} 5$ insertion in an open reading frame (phyA; putative phytase A) encoding a 373-amino acid (aa) protein containing a 28 -aa predicted signal peptide. Extracellular protein profiles revealed that a $38-\mathrm{kDa}$ band is absent in phy $A$ mutants as compared with $p h y A^{+}$ strains. A BLAST search with $p h y A$ and its deduced polypeptide sequence indicated significant similarity with conserved hypothetical proteins in Xanthomonas axonopodis pv. citri and Xanthomonas campestris pv. campestris and limited homology to secreted phytases of Bacillus species. Homology modeling with a Bacillus phytase as the template suggests that the PhyA protein has a similar six-bladed $\beta$-propeller architecture and exhibits conservation of certain critical active site residues. Phytases are enzymes that are involved in degradation of phytic acid (inositol hexaphosphate), a stored form of phosphate in plants. The phy $A$ mutants exhibit a growth deficiency in media containing phytic acid as a sole phosphate source. Exogenous phosphate supplementation promotes migration of phyA $X$. oryzae pv. oryzae mutants in rice leaves. These results suggest that the virulence deficiency of phy $A$ mutants is, at least in part, due to inability to use host phytic acid as a source of phosphate. phy $A$-like genes have not been previously reported to be involved in the virulence of any plant pathogenic bacterium.
\end{abstract}

Bacteria belonging to the genus Xanthomonas are important pathogens of many plants, and worldwide, at least 350 different plant diseases are known to be caused by various xanthomonads (Leyns et al. 1984). One member of this genus, Xanthomonas oryzae pv. oryzae, causes a serious disease of rice called bacterial leaf blight. Previously described genes that are required for virulence of $X$. oryzae pv. oryzae are: the rpfF gene, which in an as yet undetermined manner, affects iron metabolism (Chatterjee and Sonti 2002); the xadA gene, whose product is homologous to nonfimbrial adhesins of animal pathogenic bacteria (Ray et al. 2002); the gumG and gumM

Corresponding author: R. V. Sonti; Telephone: +91-40-27192577; Fax: +91-40-27160591; E-mail: sonti@ccmb.res.in or rvsonti@yahoo.com.

Nucleotide and amino acid sequence data are available in the GenBank database under accession number AY151260. genes that are involved in extracellular polysaccharide (EPS) synthesis (Dharmapuri and Sonti 1999; Rajeshwari and Sonti 2000); the $r p f C$ gene that is involved in regulation of EPS synthesis (Tang et al. 1996); the hrp and avr genes that encode components of a type III protein secretion system, its effectors, and regulators (Kamdar et al. 1993; Bai et al. 2000; Yang et al. 2000; Zhu et al. 2000); and the $x p s F$ and $x p s D$ genes, which encode components of a type II protein secretion system that is involved in secretion of xylanase (Xyn) and several other proteins (Ray et al. 2000). Besides these, certain amino acid auxotrophs of $X$. oryzae pv. oryzae have also been shown to be virulence-deficient (Yamasaki et al. 1964; Goel et al. 2001). These and other studies are summarized in the review of Shen and Ronald (2002).

In order to identify novel virulence functions of $X$. oryzae pv. oryzae, we had previously screened 1,600 Tn5gusA40induced (mTn5) (Wilson et al. 1995) X. oryzae pv. oryzae mutants (Dharmapuri 1999) for virulence deficiency on rice plants (Chatterjee and Sonti 2002). Six virulence-deficient mutants were identified. Three of these mutants (BXO1601,

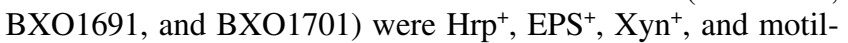
ity $^{+}$and were prototrophs. The BXO1601 mutant was characterized in an earlier study (Chatterjee and Sonti 2002) and was found to be affected in the $r p f F$ gene. In this study, we demonstrate that the virulence deficiency in BXO1691 is due to mutation in a gene named phyA, which encodes a secreted protein that is homologous to Bacillus phytase.

\section{RESULTS}

Virulence properties

of $X$. oryzae pv. oryzae mutant BXO1691.

The lesions caused by the wild-type strain are approximately 3.8 and $9 \mathrm{~cm}$ long 10 and 14 days after wound inoculation, respectively. In contrast, the lesions caused by BXO1691 are 1.2 and $3.3 \mathrm{~cm}$ long 10 and 14 days after inoculation, respectively (Fig. 1A). The BXO1691 strain also exhibited a virulence deficiency following epiphytic infection (Fig. 1B). In this mode of infection, the bacterial cells are deposited on the rice leaf surface without wounding, and the pathogen gains entry into leaves through the hydathodal openings. Under the conditions of epiphytic infection used in this study, approximately $62 \%$ of the leaves infected with the wild-type strain were found to develop visible lesions. In leaves inoculated with BXO1691, approximately $29 \%$ of the infected leaves develop lesions. These data indicate that the BXO1691 strain exhibits reduced virulence, as assayed by wound inoculation as well as infection 
efficiency. Unlike the previously described BXO1601 mutant (Chatterjee and Sonti 2002), the BXO1691 strain does not overproduce siderophores (data not shown), indicating that it is not affected in the $r p f F$ gene.
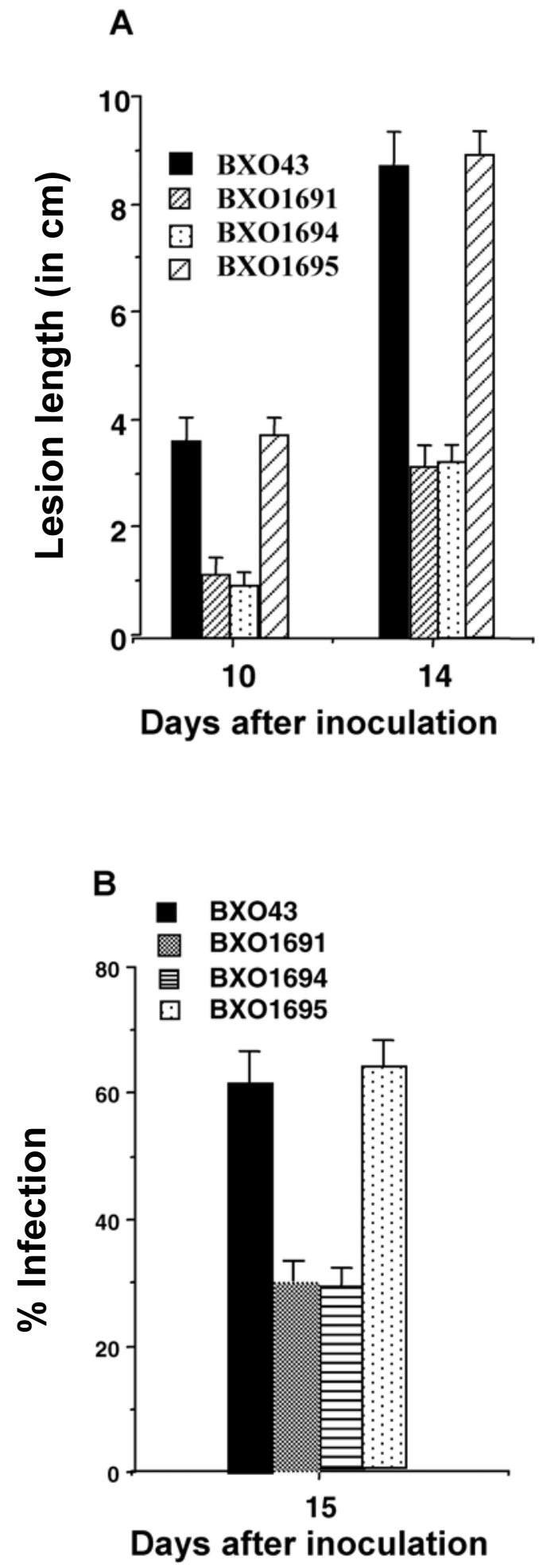

Fig. 1. phyA mutations affect Xanthomonas oryzae pv. oryzae virulence. Virulence assays were conducted by inoculating rice plants of the susceptible cultivar Taichung Native-1 (TN-1) through either A, wounding or B, epiphytic infections. Lesion lengths (A) or efficiency of infection (B) were used as a measure of virulence. $\mathrm{BXO} 43=$ wild-type strain; BXO1691 = phyA1::mTn5; BXO1694 = $\Delta p h y A ;$ and BXO1695 = $z x x-111:: \mathrm{mTn} 7$ (phy $A^{+}$recombinant). Similar results were obtained with phyA::mTn7 mutants (data not shown).
Virulence deficiency of BXO1691 is due to a mutation in the $p h y A$ gene.

The BXO1691 strain carries a single mTn5 insertion, as determined by Southern hybridization using the mTn 5 element as a probe (data not shown). A 6.5-kb ClaI fragment containing the mTn5 insertion in BXO1691 along with flanking chromosomal DNA was cloned into the ClaI site of pBluescript $\left(\mathrm{KS}^{+}\right)$ to generate the pSC20 clone. Introduction of the mTn5 insertion into a wild-type background using the pSC20 clone (discussed below) led to a virulence-deficient phenotype (data not shown). This indicates that the virulence deficiency of BXO1691 is due to the mTn5 insertion. A genomic clone containing the wild-type allele of the mutated gene was isolated using a polymerase chain reaction (PCR)-based strategy. Initially, the sequence of the region flanking the site of the mTn5 insertion in BXO1691 was obtained using pSC20 as template and primers outwardly directed from the transposon. Based on the obtained sequence, primers were designed that would PCRamplify an 807-bp fragment from this region of the genome. A $30-\mathrm{kb}$ cosmid clone ( $\mathrm{pSC} 21$ ) that includes this genomic region was identified by screening 720 cosmid clones from a genomic library of $X$. oryzae pv. oryzae (Rajagopal et al. 1999). Restriction digestion with EcoRI and Southern hybridization indicated that the insert contains six EcoRI fragments of 8, 6, 5, 4.8, 4, and $2 \mathrm{~kb}$. The mTn5 insertion in BXO1691 is in the 6-kb EcoRI fragment (data not shown). The 6-kb EcoRI fragment was cloned in pBluescript $\left(\mathrm{KS}^{+}\right)$to generate the pSC22 clone (Table 1).

A 2.374-kb region of chromosomal DNA flanking the site of mTn5 insertion in BXO1691 was sequenced (discussed below), and within this sequenced region (GenBank accession number AY151260), two incomplete open reading frames (ORFs) (ORF3 and ORF2) and one complete ORF (ORF1) were identified (Fig. 2). The mTn5 insertion is in codon 302 of ORF1, which has potential to encode a protein of 373 aa with valine as an alternative start codon instead of methionine (Fig. 2). A BLAST search (Altschul et al. 1997) with this ORF (ORF1, phyA) and its deduced polypeptide sequence indicated substantial similarity with the conserved hypothetical proteins (CHP) of $X$. axonopodis $\mathrm{pv}$. citri (accession number AAM37370; identity 91\%, similarity $95 \%$ in a stretch of 365 aa, as well as $89 \%$ nucleotide sequence identity [da Silva et al. 2002]) and X. campestris pv. campestris (accession number AAM41662; identity 87\%, similarity $92 \%$ in a stretch of 372 amino acids, as well as $86 \%$ nucleotide sequence identity [da Silva et al. 2002]). Sequence analysis of the deduced polypeptide sequence of $p h y A$, using the signal peptide prediction program SignalP (Nielsen et al. 1997), indicated that it has a potential 28-aa signal peptide, with the most likely cleavage site between amino acids 27 and 28 (APA-GR). A search through the National Center for Biotechnology Information (NCBI) conserved domain database indicates that the predicted PhyA protein exhibits weak similarity (E value $4 \mathrm{e}-05$ ) to domains in phytases (pfam02333) from Bacillus species DS11 (accession number O66037) and Bacillus subtilis (accession number P42094).

ORF3 and ORF2, which respectively flank the 5 and 3 ' ends of phyA (Fig. 2) are homologous to similarly located genes in $X$. axonopodis pv. citri and $X$. campestris pv. campestris (da Silva et al. 2002). ORF3 (partial sequence of 162 bp) exhibits $91 \%$ nucleotide sequence identity to cirA (putative TonB dependent receptor) genes of $X$. axonopodis pv. citri (accession number AAM37371) and $X$. campestris pv. campestris (accession number AAM41663), respectively. ORF2 (partial sequence of 609 bp) exhibits 86 and $85 \%$ nucleotide sequence identity to CHPencoding genes of $X$. axonopodis pv. citri (accession number AAM37369) and $X$. campestris pv. campestris (accession number AAM41661). However, ORF2 appears to be a pseudogene, as it is interrupted by two stop codons and an insertion 
of IS1114 (accession number AF232058), an X. oryzae pv. oryzae insertion sequence (Fig. 2). Interestingly, a BLAST search (Altschul et al. 1997) with the homologs of ORF2 in X. axonopodis pv. citri and $X$. campestris pv. campestris indicates similarity $\left(2 \mathrm{e}^{-11}\right)$ at the amino acid level to purple acid phos- phatases from Arabidopsis thaliana (AAG51511) and other organisms (data not shown).

Two additional transposon $(\mathrm{mTn} 7)$ insertions in the phyA $X$. oryzae pv. oryzae gene were isolated by in vitro mutagenesis (discussed below). The phyA2::mTn7 and phyA3::mTn7 inser-

Table 1. Strains and plasmids used in this study

\begin{tabular}{|c|c|c|}
\hline Strains or plasmids & Relevant characteristics $^{\mathrm{a}}$ & Reference or source \\
\hline \multicolumn{3}{|c|}{ Escherichia coli strains } \\
\hline DH5 $\alpha$ & F'/endA1 hsdR17 ( $\mathrm{rk}^{-} \mathrm{m}_{\mathrm{k}}^{+}$) supE44 thi-1 recA1 gyrA relA1 f80dlacZDM15 (lacZYA-argF) U169 & Lab collection \\
\hline S17-1 & RP4-2Tc::Mu-Kn::Tn7 pro hsdR recA & Simon et al. 1983 \\
\hline \multicolumn{3}{|l|}{ Plasmids } \\
\hline pBluescript(KS) & $\mathrm{Ap}^{\mathrm{r}}$ & Stratagene, La Jolla, CA, U.S.A. \\
\hline pUFR034 & $\mathrm{IncW} \mathrm{Nm}^{\mathrm{r}} \mathrm{Tra}^{-} \mathrm{Mob}^{+} \operatorname{mob}(\mathrm{P}) \mathrm{LacZ}^{+} \mathrm{Par}^{+} \cos$ & DeFeyter et al. 1990 \\
\hline pSC20 & $\begin{array}{l}\text { pBluescript }+6.5-\mathrm{kb} \text { ClaI fragment of chromosomal DNA including the phyA1::mTn5 insertion } \\
\text { in BXO1691 }\end{array}$ & This study \\
\hline PSC21 & pUFR034 + 30-kb genomic insert of X.oryzae pv. oryzae DNA containing phyA & This study \\
\hline $\mathrm{pSC} 22$ & pBluescript + 6-kb EcoRI fragment from pSC21 encoding phyA. & This study \\
\hline pSC23 & pSC22-phyA2::mTn7 & This study \\
\hline pSC24 & pSC22-phyA3::mTn7 & This study \\
\hline $\mathrm{pSC} 25$ & pSC22-zxx-111::mTn7 & This study \\
\hline pJQ200SK & SacB suicide vector; $s a c B \mathrm{Tra}^{-} \mathrm{Mob}^{+}, \mathrm{Gm}^{\mathrm{r}}$ & Quandt and Hynes 1993 \\
\hline $\mathrm{pSC} 26$ & pBluescript + 596-bp PCR fragment containing 73-aa in-frame deletion within phyA ( $\Delta$ phyA) & This study \\
\hline pSC27 & pJQ200SK + & This study \\
\hline \multicolumn{3}{|c|}{ Xanthomonas oryzae pv. oryzae strains } \\
\hline BXO1 & Laboratory wild type, an Indian isolate & Lab collection \\
\hline BXO43 & rif-2; derivative of $\mathrm{BXO} 1$ & Lab collection \\
\hline BXO1691 & phyA1::mTn5gusA40 rif-2; $\mathrm{Sp}^{\mathrm{r}} \mathrm{Vir}^{-}$derivative of $\mathrm{BXO} 43$ & This study \\
\hline BXO1692 & phyA2::mTn7 rif-2;: $\mathrm{Km}^{\mathrm{r}} \mathrm{Vir}^{-}$derivative of $\mathrm{BXO} 43$ & This study \\
\hline BXO1693 & phyA3::mTn7 rif- $2 ; \mathrm{Km}^{\mathrm{r}} \mathrm{Vir}^{-}$derivative of $\mathrm{BXO} 43$ & This study \\
\hline BXO1694 & $\triangle p h y A$ (73-aa in-frame deletion) rif-2; Vir $^{-}$derivative of $\mathrm{BXO} 43$ & This study \\
\hline BXO1695 & $z x x-111:: \mathrm{mTn} 7$ rif- $2 ;$ phy $A^{+}$recombinant, $\mathrm{Sp}^{\mathrm{s}} \mathrm{Km}^{\mathrm{r}} \mathrm{Vir}^{+}$derivative of $\mathrm{BXO} 1691$ & This study \\
\hline BXO1696 & $z x x-111:: \mathrm{mTn} 7$ rif- $2 ; \mathrm{Km}^{\mathrm{r}} \mathrm{Vir}^{+}$derivative of $\mathrm{BXO} 43$ & This study \\
\hline BXO99 & $z x x-1:: m T n 5$ gusA11 rif-2; $\mathrm{GUS}^{+}, \mathrm{Vir}^{+}$derivative of $\mathrm{BXO} 43$ & Rajagopal 1998 \\
\hline BXO1698 & 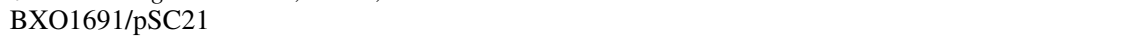 & This study \\
\hline
\end{tabular}

${ }^{a}$ rif indicates a mutation that confers rifampicin resistance. Vir $^{-}$indicates a mutation that causes virulence deficiency. $z x x l$ indicates that the location of the insertion in the genome is not determined. The $z x x-111:: \mathrm{mTn} 7$ insertion is located near the phyA gene. mTn5gusA11 carries a gus gene that is driven by a constitutively active Ptac promoter and Tn5gusA40 carries a gus gene that is without a promoter and can be used to make transcriptional fusions (Wilson et al. 1995). $\mathrm{Sp}^{\mathrm{r}}, \mathrm{Km}^{\mathrm{r}}$, and $\mathrm{Gm}^{\mathrm{r}}$ indicate resistance to spectinomycin, kanamycin, and gentamicin, respectively.
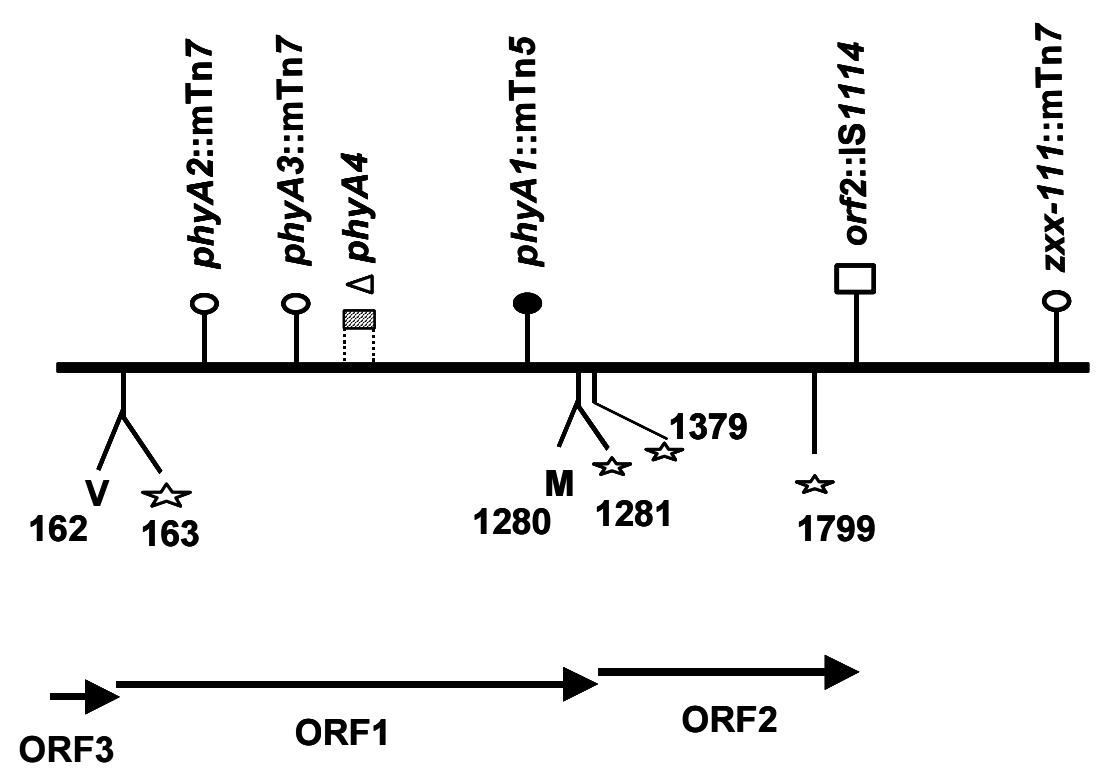

\section{$0.3 \mathrm{~kb}$}

Fig. 2. Schematic of the arrangement of open reading frames (ORFs) in a 2.374-kb genomic region of Xanthomonas oryzae pv. oryzae. M and V represent start codons of ORFs and stars represent stop codons. The stop codon for ORF3 overlaps with the start codon for ORF1, and the stop codon for ORF1 overlaps with the start codon for ORF2. Arrows represent the direction of transcription. Mutations in ORF1 affect X. oryzae pv. oryzae virulence. ORF2 and 3 extend from or into adjacent regions, respectively, and only partial sequences are available. ORF2 is interrupted by several stop codons and an insertion of IS1114, an X. oryzae pv. oryzae insertion sequence. The filled and open circles indicate, respectively, the location of mTn5 and mTn7 insertions. The region covered by the stippled box indicates the extent of deletion in phyA4. 
tions are positioned at 446 and $620 \mathrm{bp}$, respectively, within the phyA ORF (Fig. 2). The phyA mutants (BXO1692 and BXO1693) (Table 1) containing these alleles (phyA2::mTn7 and phyA3::mTn7) were generated by marker exchange in the BXO43 background and were as virulence-deficient as BXO1691 (data not shown). To rule out the possibility that the virulence deficiency of the transposon insertions in the phy $A$ ORF is due to a polar effect on the downstream truncated ORF2, an in-frame deletion of $219 \mathrm{bp}$ (corresponding to amino acid residues 194 to 266) in the phyA ORF, was introduced into the chromosome of $X$. oryzae pv. oryzae (discussed below). The $\triangle p h y A$ strain (BXO1694) was as virulence-deficient as BXO1691 in wound as well as epiphytic mode infection (Fig. $1 \mathrm{~A}$ and $\mathrm{B})$. A phy $A^{+}$recombinant (BXO1695) was obtained by replacing the $p h y A^{-}$allele in BXO1691 with the linked $z x x$ $111:: \mathrm{mTn} 7$ insertion (discussed below; Table 1, Fig. 2). The phy $A^{+}$recombinant $(\mathrm{BXO1695)}$ and a $X$. oryzae pv. oryzae strain (BXO1696, phy $A^{+}$) carrying $z x x-111:: \mathrm{mTn} 7$ exhibited a wild-type virulence phenotype (Fig. $1 \mathrm{~A}$ and $\mathrm{B}$, data shown only for BXO1695).

\section{Homology model of PhyA protein.}

The 3D-PSSM fold recognition server (Kelley et al. 2000) identified the fold of a thermostable phytase from Bacillus amyloliquefaciens (BaPhy) (protein data bank ID, 1POO) as the closest to that of the PhyA protein (E-value, $1.66 \mathrm{e}^{-08}$ ). The BaPhy structure was then used to model the 3-dimensional structure of the PhyA protein using the 3D-Jigsaw server (Bates et al. 2001). The final model comprises residues 40 to 373 of the PhyA protein, with a structure-based sequence identity of $22 \%$ to BaPhy. The validity of the model could be readily checked with the conservation of residues in the hydrophobic core of the molecule and the exposure of hydrophilic residues to the solvent. The modeled structure is a six-bladed $\beta$ propeller (Fig. 3), with each sheet highly curved and consisting of four strands. The BaPhy has been shown to possess high and low affinity calcium sites, where the high affinity sites are implicated in thermostability and the low affinity sites are impli-

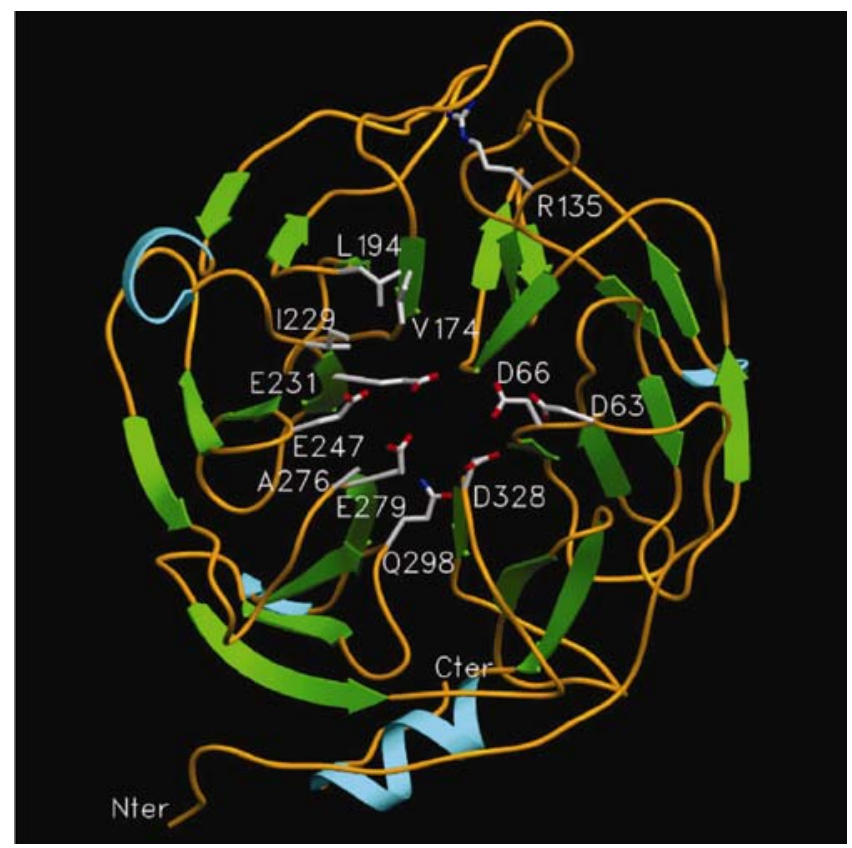

Fig. 3. A ribbon diagram of the modeled structure of PhyA. A view down the $\beta$-propeller with the active site facing upwards is shown. The crucial residues lining the active site are indicated and labeled according to the PhyA sequence. The figure was prepared using the program SETOR (Evans 1993). cated in the phytase activity (Ha et al. 2000). The model clearly shows that the lengthy loops that are involved in the binding of two high-affinity calcium ions (Ca1 and $\mathrm{Ca} 2)$ are truncated in the PhyA protein indicating, a loss of these calcium binding sites.

The active site, as identified using a high-resolution crystal structure of BaPhy (Ha et al. 2000; Shin et al. 2001), is located on the top of the $\beta$-propeller. Despite a low overall sequence identity of around $22 \%$ between BaPhy and PhyA protein, a high conservation of amino acid residues is observed in the active site region. The active site of BaPhy is predominantly occupied by acidic residues (Asp and Glu) and binds to four low-affinity calcium ions (shown to be responsible for the enzymatic activity), two phosphate ions, and water molecules. A comparison of the active site of PhyA protein and BaPhy shows that most residues involved in the binding of metal ions are highly conserved. Except for one Ca5 binding Tyr159 (Val174 in PhyA protein) and a Ca6 binding Asp258 in BaPhy (Ala276 in PhyA protein), the crucial residues involved in binding of calcium ions and phosphate 1 (Asp63, Asp66, Arg135, Glu231, Glu247, Glu279, Gln298, and Asp328) are invariant (Fig. 3). Such a high conservation of residues involved in the enzymatic mechanism cannot be coincidental and strongly suggests that the PhyA protein has a very similar function to that of phytases. This further confirms the correctness of the model, since the active site residues are coming from different parts of the primary structure of the protein.

\section{phyA encodes a secreted protein of $X$. oryzae pv. oryzae.}

Extracellular proteins from the culture supernatants of $p h y A^{+}$ and phyA mutant $X$. oryzae pv. oryzae strains (BXO43, BXO1691, BXO1692, BXO1694, BXO1695, and BXO1698) were isolated and analyzed by sodium dodecyl sulfate-polyacrylamide gel electrophoresis (SDS-PAGE) as described below. A $38-\mathrm{kDa}$ band, which is the expected size of the PhyA protein (without the $\mathrm{N}$-terminal signal peptide), is absent in phyA mutants (data shown only for BXO1691) as compared with the wild-type strain (BXO43) and is restored in a $p h y A^{+}$ recombinant, BXO1695 (Fig. 4). This band is also restored (data not shown) in BXO1698 (phyAl::mTn5/pSC21), which has the $p h y A^{+}$allele on pSC21. However, no difference was seen in the protein profiles of cytoplasmic, periplasmic, and membrane fractions from these strains (data not shown). This indicates that the phyA gene encodes a secreted protein. The $38-\mathrm{kDa}$ band from the wild-type strain was excised from the gel and subjected to in-gel trypsin digestion. The eluted polypeptide was analyzed by matrix-assisted laser desorption/ionization time-of-flight MALDI-TOF (discussed below) mass spectroscopy. The expected trypsin digestion peaks (with 0 or 1 missed cleavage site) were obtained for the deduced polypeptide sequence of $p h y A$ ORF. The $\mathrm{m} / \mathrm{z}(\mathrm{mi})$ values of five peaks obtained by MALDI-TOF matched $(\mathrm{ppm}<50)$ with two $(0$

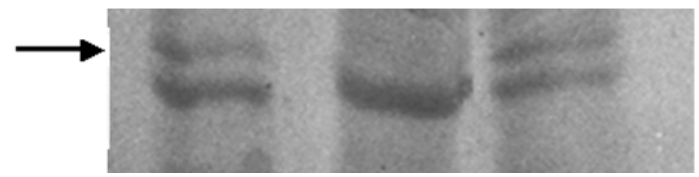

Fig. 4. Analysis of extracellular protein profiles from different strains of Xanthomonas oryzae pv. oryzae by sodium dodecyl sulfatepolyacrylamide gel electrophoresis. Lane1 = BXO43, wild-type strain; lane2 = BXO1691, phyA1::mTn5; and lane $3=\mathrm{BXO1695,} \mathrm{phyA^{+ }}$ recombinant. The arrow indicates the position of the $38-\mathrm{kDa}$ product of the phyA gene. This product is missing in the phyA mutant (lane 2) and restored in the $p h y A^{+}$recombinant (lane 3 ). Similar results were obtained in two independent experiments and with the phyA2::mTn7 mutant (BXO1692). 
missed cleavage) and three (1 missed cleavage) expected trypsin digestion fragments. A search for matches in the nonredundant protein database was performed using these peaks (discussed below). The closest match (Mowse score of 74) was with the predicted sequence of the phyA gene product. This shows that the $38-\mathrm{kDa}$ protein is very likely the phyA gene product.

\section{phyA mutants of $X$. oryzae pv. oryzae are deficient} for growth on medium containing phytic acid as a sole phosphate source.

In rich and M4 minimal media, the growth yields of phyA $X$. oryzae pv. oryzae mutants (either BXO1691 or BXO1694) and the wild-type strain (BXO43) were indistinguishable (data not shown). In modified M4 media, which contains 3 $\mathrm{mM}$ phytic acid as sole phosphate source, the growth yields of phyA mutants (BXO1691, BXO1694) were considerably reduced (about 100-fold less) compared with that of $\mathrm{BXO} 43$ and the phy $A^{+}$recombinant BXO1695 (Fig. 5). In modified

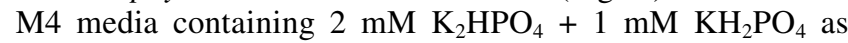
sole phosphate source, the growth yields of phyA mutants (BX01691, BXO1694) were similar to those of the $p h y A^{+}$ strains (BXO43, BXO1695) (Fig. 5). Addition of $2 \mathrm{mM}$ $\mathrm{K}_{2} \mathrm{HPO}_{4}+1 \mathrm{mM} \mathrm{KH} \mathrm{PO}_{4}$ to the modified M4 medium containing $3 \mathrm{mM}$ phytic acid also rescued the growth yield deficiency of phyA mutants (data not shown). These results indicate that phyA mutants exhibit a growth deficiency in medium containing phytic acid as a sole phosphate source.

\section{Exogenous phosphate promotes growth}

of phyA $X$. oryzae. pv. oryzae mutants in rice leaves.

In order to determine whether exogenous phosphate would rescue the growth defect of phyA X. oryzae pv. oryzae mutants in rice leaves, inorganic phosphate $\left(2 \mathrm{mM} \mathrm{K}_{2} \mathrm{HPO}_{4}+1 \mathrm{mM}\right.$ $\mathrm{KH}_{2} \mathrm{PO}_{4}$ ) was added to the detached rice leaves, which were maintained in vitro as described below. These detached rice leaves were inoculated with $X$. oryzae pv. oryzae strains, and the distance migrated within the leaves in 3 days was estimated. The distances migrated by the wild-type $X$. oryzae pv. oryzae strain (BXO43) are approximately 3 and $3.6 \mathrm{~cm}$ without and with 2 $\mathrm{mM} \mathrm{K} \mathrm{HPO}_{4}+1 \mathrm{mM} \mathrm{K \textrm {K } _ { 2 }} \mathrm{PO}_{4}$ supplementation, respectively (Fig. 6). phyA mutants of $X$. oryzae pv. oryzae migrated $0.9 \mathrm{~cm}$ in rice leaves dipped in medium without any phosphate supplementation, which increased very substantially to $3.4 \mathrm{~cm}$ in rice leaves in phosphate-supplemented medium (Fig. 6).

\section{phyA::gus expression is affected}

by phosphate content in the growth medium.

Expression of the phyA gene was estimated after $48 \mathrm{~h}$ of growth under low and high phosphate conditions, using a chromosomal phyA::gus fusion (BXO1691). GUS activity in low phosphate medium $\left(2 \mathrm{mM} \mathrm{K} \mathrm{HPO}_{4}+1 \mathrm{mM} \mathrm{KH}_{2} \mathrm{PO}_{4}\right)$ is $4.9 \pm 0.5 \mathrm{nM} 4$-MU (4-methylumbelliferone) per min per $10^{7}$ CFU. GUS activity in M4 medium (high phosphate medium, $30 \mathrm{mM} \mathrm{KH} \mathrm{PO}_{4}+60 \mathrm{mM} \mathrm{K}_{2} \mathrm{HPO}_{4}$ ) is $2.1 \pm 0.6 \mathrm{nM} \mathrm{4-MU}$ per min per $10^{7} \mathrm{CFU}$. These results indicate that the phyA::gus expression is two- to threefold higher on low phosphate medium as compared with high phosphate medium. A similar pattern of phyA::gus expression was observed in strains that were $\mathrm{PhyA}^{+}$due to the presence of the phyA gene on a complementing plasmid (BXO1698, phyA1::Tn5gusA40/pSC21) (Table 1). These different growth conditions did not have any effect (data not shown) on expression of a gus gene driven by a constitutively expressed Ptac promoter in X. oryzae pv. oryzae BXO99 (Table 1).

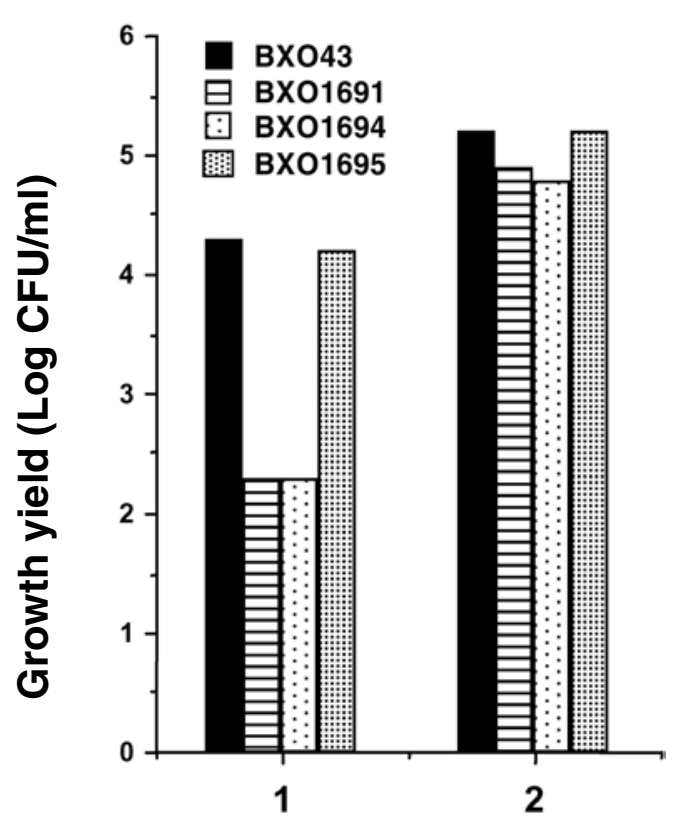

Growth Conditions

Fig. 5. phyA Xanthomonas oryzae pv. oryzae mutants exhibit a growth deficiency in medium containing phytic acid as a sole phosphate source. Growth yields of different $X$. oryzae pv. oryzae strains grown in modified M4 medium containing, as sole phosphate source, $3 \mathrm{mM}$ phytic acid (1) and $2 \mathrm{mM} \mathrm{K}_{2} \mathrm{HPO}_{4}+1 \mathrm{mM} \mathrm{KH_{2 }} \mathrm{PO}_{4}$ (2). Growth yield was calculated as $\log$ $(\mathrm{CFU} / \mathrm{ml}$ [at $46 \mathrm{~h}$ ] - CFU/ml [at $0 \mathrm{~h}])$. BXO43, wild type strain; BXO1691,

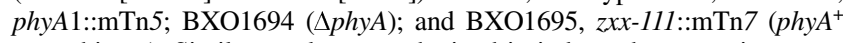
recombinant). Similar results were obtained in independent experiments as well as with phyA::mTn7 mutants (data not shown).

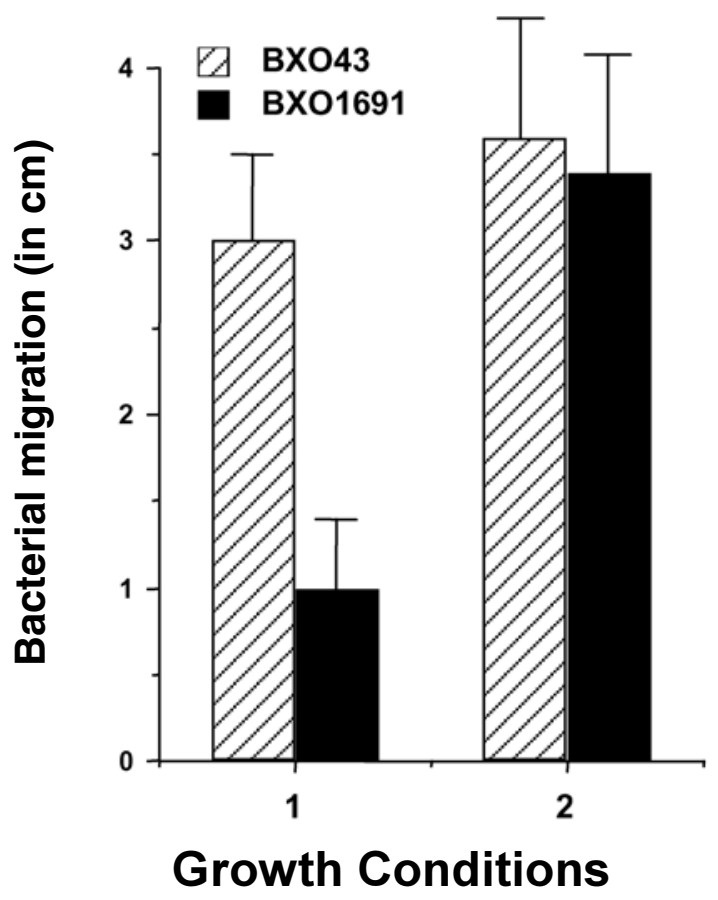

Fig. 6. Exogenous phosphate supplementation promotes growth of phyA Xanthomonas oryzae $p v$. oryzae mutants in rice leaves. Wild-type (BXO43) and phyA1::mTn5 mutant (BXO1691) strains were inoculated on detached rice leaves maintained in media, with (1) or without (2) phosphate supplementation. Distance migrated in rice leaves was estimated 3 days postinfection. Error bars indicate the standard deviation of readings from five inoculated leaves. Similar results were obtained in independent experiments as well as with BXO1692, the phyA2::mTn7 mutant (data not shown). 


\section{DISCUSSION}

We report the characterization of BXO1691, a novel $X$. oryzae pv. oryzae virulence-deficient mutant. This strain exhibits a reproducible virulence deficiency following wound as well as epiphytic infection but is proficient for characteristics that have been reported to be affected in a number of previously isolated $X$. oryzae pv. oryzae virulence-deficient mutants. Sequence analysis indicates that this strain is mutated in a gene, $p h y A$, that has not been previously reported to be involved in the virulence of any plant pathogenic bacterium. Homologs of this gene are present in the genomes of $X$. campestris pv. campestris as well as $X$. axonopodis pv. citri.

Sequence analysis of the phyA ORF using the conserved domain database indicates that it has low similarity to domains present in phytases from Bacillus species. Phytases (myoinositol hexakis-phosphate 3- and 6-phosphohydrolases), are mostly secreted phosphatase enzymes that hydrolyze phytic acid (myo-inositol hexaphosphate) to less-phosphorylated myo-inositol derivatives (Kerovuo et al. 1998; Wyss et al. 1999). Phytic acid is considered to be a major stored form of the total phosphorus in cereals and legumes (Reddy et al. 1989). It is present in large amounts in seeds and at varying amounts in other plant parts, such as roots, crown, leaves, and pollen. The Bacillus phytases are in a novel class of phytases that require calcium for activity and do not exhibit the characteristic RHGXRXP motif that is present in the active site of members of the phytase subfamily of histidine acid phosphatases (Kerovuo et al. 1998). The predicted sequence of the PhyA protein does not have a RHGXRXP motif

The phyA gene product has a predicted signal peptide, and our results indicate that, like the Bacillus phytase, it is secreted into the growth medium. This suggests that the protein acts on host tissue or compounds therein to facilitate virulence. One possibility is that it promotes the utilization of host phytic acid as a source of phosphate for the bacterium. The observed growth deficiency of phyA mutants as compared with $p h y A^{+}$ strains, on medium containing phytic acid as a sole phosphate source is consistent with this possibility. Inorganic phosphate supplementation in the detached leaf assay promotes growth and migration of the phyA $X$. oryzae pv. oryzae mutants within rice leaves. This suggests that an inability to source sufficient phosphate is a major contributor to the virulence deficiency of the phyA $X$. oryzae pv. oryzae mutants. Expression of a phyA::gus fusion is higher in low phosphate medium compared with high phosphate medium. These results should be confirmed by other techniques such as reverse transcriptase (RT)PCR or Northern blot analyses. Nevertheless, they are consistent with the idea that the phyA gene is involved in promoting phosphate metabolism in $X$. oryzae pv. oryzae.

Although the phosphate supplementation experiments, both in vitro and in vivo, argue strongly for a role for phytic acid in phosphate supply, other forms of inositol polyphosphates occur, albeit at low levels in plants. Many of them are implicated in signal transduction and processing. The possibility exists that some of these inositol polyphosphates might be PhyA substrates. In addition, phytic acid itself has also been suggested to have a role as a signaling molecule in plants (Lemtiri-Chlieh et al. 2000). This raises the intriguing possibility that PhyA activity might interfere with signaling processes in plants.

Our data indicate that, with respect to the region that has been sequenced in this study, the gene order is conserved between $X$. oryzae pv. oryzae, X. campestris pv. campestris, and $X$. axonopodis pv. citri. Interestingly, although orf 2 is truncated in $X$. oryzae pv. oryzae, the products of the corresponding ORFs from $X$. campestris pv. campestris and $X$. axonopodis pv. citri are homologous to purple acid phosphatases from Arabidopsis thaliana and other organisms. The presence of a putative purple acid phosphatase at this location might be significant, as genes that participate in related functions tend to be encoded adjacent to each other in bacterial genomes. Furthermore, the stop codon for the phyA ORF overlaps with the start codon for the putative purple acid phosphatase ORF in X. axonopodis pv. citri (da Silva et al. 2002) and $X$. oryzae pv. oryzae. This kind of arrangement has been observed in bacteria for proteins that function together in multicomponent complexes. Therefore, the putative xanthomonad purple acid phosphatase might also be involved in phytic acid metabolism. In this regard, it is interesting to note that a soybean phytase exhibits sequence similarity with purple acid phosphatases (Hegeman and Grabau 2001). The reason for conversion of the putative purple acid phosphatase gene into a pseudogene in $X$. oryzae pv. oryzae is not known. It is possible that the presence of both functions is of selective advantage for virulence on the hosts that are infected by $X$. campestris pv. campestris and $X$. axonopodis pv. citri, while one function will suffice in $X$. oryzae pv. oryzae.

The experimental results, together with the modeled structure, strongly suggest that the PhyA protein has a role in the degradation of phytic acid. However, as per the modeled structure, differences do exist between the PhyA protein and BaPhy in residues lining one side of the active site, which are involved in the binding of phosphate 2. The residues of BaPhy in that region, namely, Asn99, Tyr159, Lys179, and Gln209 have been changed to Gly112, Val174, Leu194, and Ile229 in PhyA (Fig. 3). These changes, which are also conserved in $X$. campestris pv. campestris and $X$. axonopodis pv. citri (data not shown), at the phosphate 2 binding site make it highly hydrophobic. Whether these differences reflect a change in substrate specificity arising from an inability to bind the phosphate 2 or a different binding mode of the phytic acid in the active site, and hence, a change in the enzymatic mechanism remains to be seen. However, the striking conservation of many crucial residues in the active site of PhyA indicates a similar function as that of BaPhyA.

We have so far not been able to detect phytase activity in either extracellular culture supernatants or cell extracts of wildtype $X$. oryzae pv. oryzae by following the assay protocol for BaPhy (Kerovuo et al. 1998). The inability to detect phytase activity may be due to the following: i) the enzymatic activity may be affected by the protein isolation procedure, or ii) the assay conditions that we followed may not be optimum for the $X$. oryzae pv. oryzae phytase. The predicted differences between the active sites of PhyA and BaPhy suggest that the latter explanation may be more likely. We are currently attempting various isolation and reaction parameters in order to determine if the phyA gene does, indeed, encode a phytase.

In summary, we describe the identification of phyA, a novel X. oryzae pv. oryzae virulence gene. The phyA gene encodes a secreted protein, and our data indicate that it is involved in promoting utilization of phytic acid as a phosphate source. Homologs of this gene are present in other xanthomonads, raising the possibility that it might be involved in the virulence of other bacteria besides $X$. oryzae pv. oryzae. Future work would be aimed at determining the biochemical activity of the PhyA protein and understanding its exact role in the virulence of $X$. oryzae pv. oryzae.

\section{MATERIALS AND METHODS}

Bacterial strains, media, etc.

All bacterial strains and plasmids used are listed in Table 1. $X$. oryzae pv. oryzae strains were grown at $28^{\circ} \mathrm{C}$ in either pep- 
tone sucrose (PS) medium (Tsuchiya et al. 1982) or the modified Miller's minimal medium, M4 (Kelemu and Leach 1990)

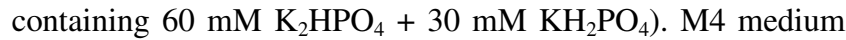
containing $2 \mathrm{mM} \mathrm{K}{ }_{2} \mathrm{HPO}_{4}+1 \mathrm{mM} \mathrm{KH}_{2} \mathrm{PO}_{4}$ was considered "low phosphate" medium. At this concentration of phosphate, growth of $X$. oryzae pv. oryzae was found to be severely affected. Growth of $X$. oryzae pv. oryzae practically ceased at a lower phosphate concentration $\left(0.66 \mathrm{mM} \mathrm{K}_{2} \mathrm{HPO}_{4}+0.33 \mathrm{mM}\right.$ $\mathrm{KH}_{2} \mathrm{PO}_{4}$ ). Where necessary, $3 \mathrm{mM}$ phytic acid was added, either as sole phosphate source in M4 medium or as a supplement to "low phosphate" M4 medium. Escherichia coli strains were grown in Luria-Bertani medium (Miller 1992) at $37^{\circ} \mathrm{C}$. The concentrations of antibiotics used were: rifampicin (Rf), $50 \mu \mathrm{g} \mathrm{ml}^{-1}$; spectinomycin (Sp), $50 \mu \mathrm{g} \mathrm{ml}^{-1}$; ampicillin (Ap), $100 \mu \mathrm{g} \mathrm{ml}^{-1}$; kanamycin $(\mathrm{Km}), 50 \mu \mathrm{g} \mathrm{ml}^{-1}$ for E. coli and $15 \mu \mathrm{g}$ $\mathrm{ml}^{-1}$ for $X$. oryzae pv. oryzae; chloramphenicol $(\mathrm{Cm}), 20 \mu \mathrm{g}$ $\mathrm{ml}^{-1}$; cycloheximide (Cy), $75 \mu \mathrm{g} \mathrm{ml}^{-1}$ was used when necessary to suppress fungal contamination; cephalexin (Cp), $20 \mu \mathrm{g} \mathrm{ml}^{-1}$; and gentamycin $(\mathrm{Gm}), 30 \mu \mathrm{g} \mathrm{ml}^{-1}$ for E. coli and $15 \mu \mathrm{g} \mathrm{ml}^{-1}$ for $X$. oryzae pv. oryzae. X. oryzae pv. oryzae is naturally resistant to $\mathrm{Cp}$.

\section{Virulence assays on rice plants.}

Greenhouse-grown rice plants (55-day-old) of the susceptible rice cultivar Taichung Native-1 (TN-1) were inoculated by clipping leaf tips with sterile scissors dipped in cultures $\left(10^{7}\right.$ cells per $\mathrm{ml}$ resuspended in sterile double distilled water [DDW]) of X. oryzae pv. oryzae (Kauffman et al. 1973). The plants were incubated in a greenhouse with minimum and maximum temperatures of approximately 25 and $30^{\circ} \mathrm{C}$, respectively, and a relative humidity of approximately $60 \%$. Lesion lengths were measured at regular intervals. No lesions were observed in control experiments in which the leaves were clipped with scissors dipped in water. In each experiment, 15 leaves were inoculated, and the values are presented as mean lesion length \pm standard deviation. Similar results were obtained in independent experiments. For epiphytic infections, 40- to 50-day-old $\mathrm{TN}-1$ rice plants were placed inside the greenhouse within a humidity chamber (made of plexiglass sheets) for $24 \mathrm{~h}$ before infection. Inoculations were done by dipping the tips of rice leaves (to a distance of $4 \mathrm{~cm}$ from the leaf tip) in a bacterial suspension carrying $10^{9} \mathrm{CFU} \mathrm{ml} \mathrm{m}^{-1}$ for 5 to $10 \mathrm{~s}$. Plants were kept in the humidity chamber for an additional week. Subsequently, the plants were transferred to a greenhouse bench, and the frequency of lesion formation was determined 15 days after inoculation. In each experiment, 20 leaves were inoculated, and the mean \pm standard deviation of data from three independent experiments are presented.

\section{Cloning of the mTn5 insertion from BXO1691.}

Genomic DNA of BXO1691 was isolated as described by Leach and associates (1990) and digested to completion with ClaI (New England Biolabs [NEB], Beverly, MA, U.S.A.), which does not cut within the mTn5 element (Wilson et al. 1995). pSC20 was obtained after ligation of this DNA into the ClaI site of $\mathrm{pBSKS}^{+}$and selecting E. coli $\mathrm{DH} 5 \alpha$ transformants on $\mathrm{LB}$ containing Ap and $\mathrm{Sp}\left(\mathrm{mTn} 5\right.$ encodes $\left.\mathrm{Sp}^{\mathrm{r}}\right)$. A 6.5-kb ClaI fragment is present in pSC20.

\section{Isolation of a genomic clone containing the phyA gene.}

Individual clones (720 with an average insert size of $30 \mathrm{~kb}$ ) from a genomic library of $X$. oryzae pv. oryzae (Rajagopal et al. 1999) maintained in DH5 $\alpha$ were pooled in groups of twelve. The pooled cosmid clones were grown and cosmid DNA was isolated by the alkaline lysis method (Sambrook et al. 1989). Pooled plasmid DNA (30 ng) was used for PCR, as described by Rajeshwari and Sonti (2000), using phyA-specific forward (GAATTCAGCGGCAAGCGGCTGCGCGTGGT [phyF]) and reverse (GAATTCATATCGCGCCAATCGAACGCGGAC [phyR]) primers (underline indicates the incorporation of EcoRI restriction enzyme site at the $5^{\prime}$ ends of the primers). One out of 60 cosmid pools gave the expected size band (807 bp) with the phyF and phyR primers. The 12 individual clones of the positive pool were again screened by PCR, using the same forward and reverse primers. One positive clone (pSC21) with a 30-kb insert was characterized further. The clone pSC22 was obtained by ligating a 6-kb EcoRI fragment from pSC21 into the EcoRI site of $\mathrm{pBSKS}^{+}$(this 6-kb fragment hybridized to the $6.5-\mathrm{kb}$ ClaI fragment from $\mathrm{pSC} 20$ ).

\section{Transposon mutagenesis and marker exchange.}

Mini-transposon $7\left(\mathrm{mTn} 7 ; \mathrm{Km}^{\mathrm{r}}\right)$ insertions were obtained on the pSC22 clone by using an in vitro transposition kit (Genome Priming System, NEB), as per manufacturer's instructions. Plasmids were isolated and the insertions were localized on either the insert or the vector by restriction analysis. Two different $\mathrm{mTn} 7\left(\mathrm{Km}^{\mathrm{r}}\right)$ insertions on the cloned DNA in pSC22 (represented by pSC23 and pSC24) (Table 1) were found by sequencing to be in the phyA gene. One of the mTn7 insertions, $z x x-111:: \mathrm{mTn} 7$, was found by sequencing to be downstream of the site of IS1114 insertion in orf2 (pSC25) (Table 1; Fig. 2) and was used as a linked insertion to obtain $p h y A^{+}$recombinants by allelic exchange with the phyAl::mTn5 mutation in the BXO1691 background.

Marker exchange was done by electroporating $300 \mathrm{ng}$ plasmid DNA (pSC20, pSC23, pSC24, and pSC25) individually into competent cells of BXO43 (wild-type strain), and pSC25 was electroplated into competent cells of BXO1691. The transformants were grown in PS for $2 \mathrm{~h}$ and then plated on peptone sucrose agar (PSA) + Km (for mTn7) or PSA + Sp (for mTn5). Colonies that were either $\mathrm{Ap}^{\mathrm{s}} \mathrm{Km}^{\mathrm{r}}$ (for $\mathrm{mTn} 7$ ), $\mathrm{Ap}^{\mathrm{s}} \mathrm{Sp}^{\mathrm{r}}$ (for $\mathrm{mTn} 5$ ), or $\mathrm{Ap}^{\mathrm{s}} \mathrm{Km}^{\mathrm{r}} \mathrm{Sp}^{\mathrm{s}}$ (for obtaining phy $A^{+}$recombinants in the BXO1691 background) were analyzed by Southern hybridization to confirm that marker exchange had occurred as expected.

\section{Generation of an in-frame phy $A$ deletion $(\triangle$ phyA).}

Using pSC22 as template DNA and two primer pairs (GAATTCAGCGGCAAGCGGCTGCGCGTGGT [phyF] [underline indicates the incorporation of EcoRI restriction enzyme site at the $5^{\prime}$ end of the primer] and CTGCAGTT CGGCCAATGGCGGCGGCAGA [delR1] [underline indicates the incorporation of Pst I restriction enzyme site at the $5^{\prime}$ end of the primer] and CTGCAGCGCGATCTCGGCA CCGGGTTG [delF3] [underline indicates the incorporation of Pst I restriction enzyme site at the $5^{\prime}$ end of the primer] and GAATTCATATCGCGCCAATCGAACGCGGAC [phyR] [underline indicates the incorporation of EcoRI restriction enzyme site at the 5' end of the primer]), 303- and 299-bp fragments were amplified by PCR, as described by Rajeshwari and Sonti (2000). The amplified fragments were digested with PstI restriction enzyme. The PstI-digested 303- and 299-bp fragments were ligated, and the ligation product was PCR-amplified with phyF and phyR primers to obtain a 596bp fragment. The 596-bp fragment, which now contained the EcoRI restriction enzyme sites at the 5 and $3^{\prime}$ ends, was digested with $E c o$ RI and ligated into the EcoRI site of $\mathrm{pBSKS}^{+}$ to generate pSC26. Sequencing of pSC26 confirmed that the 73-aa deletion and a 6-bp (PstI restriction enzyme site CTGCAG) insertion had taken place and that no other changes had occurred in the target phyA sequence. The 596bp cloned insert in pSC26 was separated by digestion with XhoI and NotI restriction enzymes (which flank the EcoRI 
site of $\left.\mathrm{pBSKS}^{+}\right)$and was ligated to the XhoI and NotI site of pJQ200SK (SacB suicide vector with $\mathrm{Gm}^{\mathrm{r}}$ selectable marker [Quandt and Hynes 1993]) to generate pSC27. pSC27 plasmid DNA (300 ng) was electroporated in the wild-type $X$. oryzae pv. oryzae (BXO43) strain. The transformants were grown in PS for $2 \mathrm{~h}$ and then plated on nutrient agar (Difco, Detroit) plates containing Gm. Single recombinant colonies that were $\mathrm{Gm}^{\mathrm{r}}$ sucrose ${ }^{\mathrm{s}}$ were grown in liquid media containing $0.3 \%$ beef extract and $0.5 \%$ peptone (HiMedia; Mumbai, India). Saturated cultures of bacteria $(3 \mathrm{ml})$ were plated on PSA plates containing 10\% sucrose. Double recombinants, which were sucrose $\mathrm{e}^{\mathrm{r}} \mathrm{Gm}^{\mathrm{s}}$ were checked by Southern hybridization, PCR, and sequencing to confirm that the 73-aa deletion had been incorporated into the phyA gene on the $X$. oryzae pv. oryzae chromosome.

\section{Separation of proteins by SDS-PAGE.}

$X$. oryzae pv. oryzae strains were grown on M4 media containing $14.5 \mathrm{mM} \mathrm{K} \mathrm{HPO}_{4}+10 \mathrm{mM} \mathrm{KH_{2 }} \mathrm{PO}_{4}$ as sole phosphate source. Saturated cultures of bacteria $(500 \mathrm{ml})$ were centrifuged at $17,000 \times g$ for $10 \mathrm{~min}$. The supernatant was taken as the extracellular fraction. Proteins from extracellular fractions were separated by SDS-PAGE (Laemmli 1970). The gels were stained with silver nitrate as described by Sambrook and associates (1989). The molecular mass markers used were obtained from Pharmacia Biotechnology (Uppsala, Sweden).

\section{Peptide mass fingerprinting.}

The gel slice containing the $38-\mathrm{kDa}$ protein was cut into approximately $1-\mathrm{mm}^{3}$ pieces and destained with $300 \mu \mathrm{l}$ of a solution containing $10 \mathrm{mM}$ potassium ferricyanide and 50 $\mathrm{mM}$ sodium thiosulfate. Trypsin (15 $\mu \mathrm{l}$ sequencing grade modified, $20 \mu \mathrm{g}$ per $\mathrm{ml}$ in $25 \mathrm{mM}$ ammonium bicarbonate) (Promega, Madison, WI, U.S.A.) was used for in-gel digestion. Extraction of the digested peptides was done by soaking the gel pieces in $100 \mu \mathrm{l}$ of a solution containing $50 \%$ acetonitrile and 5\% trifluoroacetic acid for $60 \mathrm{~min}$ and drying the sample in speed-vac to complete dryness. Reconstitution of the dried sample was done by adding $3 \mu \mathrm{l}$ of a solution containing $50 \%$ acetonitrile and $0.1 \%$ trifluoroacetic acid. Reconstituted peptide solution $(0.5 \mu \mathrm{l})$ was mixed with fresh $\alpha$ cyano-4-hydroxycinnamic acid solution in 50\% acetonitrile:0.1\% trifluoroacetic acid ( $\mathrm{vol} / \mathrm{vol})$ on MALDI plate for MALDI-TOF mass spectrometer (Voyager DE-STR; PerSeptive Biosystems, Foster City, CA, U.S.A.). The expected trypsin digestion peaks (with 0 or 1 missed cleavage sites) were obtained for the deduced polypeptide sequence of phyA ORF using the MS-Digest, a program for in silico enzymatic digestion of a protein sequence found on the University of California San Francisco ProteinProspector website. The experimental peaks, which matched those of the expected fragments, with either 0 or 1 missed cleavage site and ppm $<50$ were identified and scanned with the nonredundant protein database to obtain a probability-based Mowse score using the MASCOT program. Mowse scores greater than 68 are considered to be significant $(p<0.05)$.

\section{Growth yields of $X$. oryzae pv. oryzae strains.}

$X$. oryzae pv. oryzae strains were grown overnight in $3 \mathrm{ml}$ PS and were diluted 1,000-fold into $20 \mathrm{ml}$ of M4 media containing either $2 \mathrm{mM} \mathrm{K}_{2} \mathrm{HPO}_{4}+1 \mathrm{mM} \mathrm{KH}_{2} \mathrm{PO}_{4}$ or $3 \mathrm{mM}$ phytic acid (Sigma. St. Louis) as sole phosphate source. Growth yields were determined in cultures shaken at $28^{\circ} \mathrm{C}$ and 200 rpm. Aliquots of $200 \mu \mathrm{l}$ were taken out and dilution-plated on PSA to determine the number of CFU immediately after inoculation $(0 \mathrm{~h})$ and after $46 \mathrm{~h}$ of growth. Growth yield was calculated as $\log (\mathrm{CFU} / \mathrm{ml}$ [at $46 \mathrm{~h}]-\mathrm{CFU} / \mathrm{ml}$ [at $0 \mathrm{~h}])$.
Exogenous phosphate supplementation and bacterial migration in rice leaves.

Leaves of 40-day-old greenhouse-grown rice plants of the susceptible rice cultivar TN-1 were cut with scissors $2 \mathrm{~cm}$ above the junction of the leaf blade and sheath and were dipped in 250-ml conical flasks (30 leaves per flask) containing $200 \mathrm{ml}$ of $0.1 \%$ glucose in DDW, as described previously (Chatterjee and Sonti 2002), with or without $2 \mathrm{mM} \mathrm{K}_{2} \mathrm{HPO}_{4}+$ $1 \mathrm{mM} \mathrm{KH} \mathrm{PO}_{4}$ (Merck, Darmstadt, Germany). The addition of glucose helped to maintain the detached rice leaves in a fresh condition. The leaves were maintained for $24 \mathrm{~h}$ on a laboratory bench top, prior to inoculation with different strains of $X$. oryzae pv. oryzae by the leaf-clip method as described by Kauffman and associates (1973). Infected leaves (3 days postinfection) were surface-sterilized by dipping in $2 \%$ (vol/vol) sodium hypochlorite (Loba Chemie, Mumbai, India) for $2 \mathrm{~min}$ and washing twice in sterile water. Sterilized leaves were cut into $1-\mathrm{cm}$ pieces from the bottom of the leaf to the top (site of inoculation) and were incubated on PSA media containing Rf + $\mathrm{Cp}+\mathrm{Cy}$. After 1 to 3 days, colonies were formed by the bacterial ooze from the cut ends of rice leaf pieces, and the distance of bacterial migration was estimated.

\section{Assay of phyA::gus expression.}

$X$. oryzae pv. oryzae strains were grown in $3 \mathrm{ml}$ of media for $48 \mathrm{hr}$ and were harvested by centrifugation $(10,000 \mathrm{rpm}$ for 2 min). Culture supernatants were discarded, and the cell pellet was washed with sterile DDW and was resuspended in $500 \mu \mathrm{l}$ of DDW. GUS activity in $20 \mu \mathrm{l}$ of cell suspension was assayed in GUS assay buffer (total reaction volume of $1 \mathrm{ml}$ ) containing $1 \mathrm{mM}$ 4-methylumbelliferyl- $\beta$-D-glucuronide, $50 \mathrm{mM}$ $\mathrm{NaH}_{2} \mathrm{PO}_{4}, 10 \mathrm{mM}$ EDTA, $0.1 \%$ sarcosyl, and $10 \mathrm{mM} \beta$-mercaptoethanol, as per Jefferson and associates (1987). After 10 min of incubation, a 100- $\mu$ l aliquot was removed, and the reaction was stopped by adding this to $500 \mu \mathrm{l}$ of $0.2 \mathrm{M}$ sodium carbonate. Fluorescence was measured on a Spectra Max Gemini XS dual scanning microplate spectrofluorimeter (Molecular Devices, Sunnyvale, CA, U.S.A.), with reference to a standard curve of 4-MU in $0.2 \mathrm{M}$ sodium carbonate. Bacterial numbers were measured after plating serial 10-fold dilutions of resuspended bacterial cells.

\section{Plasmid preparation, Southern hybridization, DNA sequencing, and sequence analysis.}

Plasmid DNA was isolated by the alkaline lysis method (Sambrook et al. 1989). Restriction digestions were performed using enzymes obtained from NEB, as recommended by the supplier. Southern hybridizations were performed as described by Rajeshwari and Sonti (2000). Primers that are outwardly directed from $\mathrm{mTn} 5$ were used to obtain the sequence of DNA flanking the phyAl::mTn5 insertion, and the sequence obtained was further extended by primer walking, using pSC21 as a template. The mTn7-specific primers provided in the Genome Priming System kit from NEB were used to sequence the $\mathrm{mTn} 7$ insertion sites. The sequencing reactions, electrophoresis, and sequence data analysis were performed with an ABI Prism 3700 automated DNA sequencer (Perkin-Elmer, Foster City, CA, U.S.A.). Homology and conserved domain searches were performed in the NCBI database, using the BLAST algorithm (Altschul et al. 1997). Prediction of signal peptide and ORFs was done by using the signal peptide prediction program, Signal P server (Nielsen et al. 1997) and the NCBI ORF finder program.

\section{Molecular model of the PhyA protein.}

The fold of the 373-aa residue sequence of the PhyA protein was predicted using the 3D-PSSM protein fold recogni- 
tion (threading) server (Kelley et al. 2000). The top-ranking model (E-value 1.66e-08) from the server was then fed into the 3D-JIGSAW protein comparative modeling server (Bates et al. 2001). After a minor manual adjustment of the sequence alignment, the final model was obtained. The model was viewed and checked using the program $\mathrm{O}$ (Jones et al. 1991) and was compared with that of the template and related structures.

\section{ACKNOWLEDGMENTS}

We thank M. Wyss for kindly providing phytic acid. We acknowledge the help of M. Sultana for primer synthesis, N. Nagesh for DNA sequencing, and C. Sundaram, M. V. Jagannadham, and V. M. Dhople for peptide mass fingerprinting. We thank two anonymous reviewers for their comments. S. Chatterjee was supported by a fellowship from the Council of Scientific and Industrial Research (CSIR), Government of India.

\section{LITERATURE CITED}

Altschul, S. F., Madden, T. L., Schaffer, A. A., Zhang, J., Zhang, Z. Miller, W., and Lipman, D. J. 1997. Gapped BLAST and PSI-BLAST: A new generation of protein database search programs. Nucleic Acids Res. 25:3389-3402.

Bai, J., Choi, S. H., Ponciano, G., Leung, H., and Leach, J. E. 2000. Xanthomonas oryzae pv. oryzae avirulence genes contribute differently and specifically to pathogen aggressiveness. Mol. Plant-Microbe Interact. 13:1322-1329.

Bates, P. A., Kelley, L. A., MacCallum, R. M., and Sternberg, M. J. E. 2001. Enhancement of protein modeling by human intervention in applying the automatic programs 3D-JIGSAW and 3D-PSSM. Protein Struct. Funct. Genet. Suppl 5:39-46.

Chatterjee, S., and Sonti, R. V. 2002. rpfF mutants of Xanthomonas oryzae pv. oryzae are deficient for virulence and growth under low iron conditions. Mol. Plant-Microbe Interact. 15:463-471.

da Silva, A. C., Ferro, J. A., Reinach, F. C., Farah, C. S., Furlan, L. R., et al. 2002. Comparison of the genomes of two Xanthomonas pathogens with differing host specificities. Nature 417:459-463.

DeFeyter, R., Kado, C. I., and Gabriel, D. W. 1990. Small stable shuttle vectors for use in Xanthomonas. Gene 88:65-72.

Dharmapuri, S. 1999. Application of Tn5 derivatives in understanding rice-Xanthomonas oryzae interaction. Ph.D. thesis. Jawaharlal Nehru University, New Delhi, India.

Dharmapuri, S., and Sonti, R. V. 1999. A transposon insertion in the gum $G$ homologue of Xanthomonas oryzae pv. oryzae causes loss of extracellular polysaccharide production and virulence. FEMS (Fed. Eur. Microbiol. Soc.) Lett. 179:53-59.

Evans, S. V. 1993. SETOR: Hardware-lighted three-dimensional solid model representation of macromolecules. J. Mol. Graph. 11: 134-138.

Goel, A. K., Rajagopal, L., and Sonti, R. V. 2001. Pigment and virulence deficiencies associated with mutations in the aroE gene of Xanthomonas oryzae pv. oryzae. Appl. Environ. Microbiol. 67:245-250.

Ha, N.-C., Oh, B.-C., Shin, S., Kim, H.-J., Oh, T.-K., Kim, Y.-O., Choi, K. Y., and Oh, B.-H. 2000. Crystal structures of a novel, thermostable phytase in partially and fully calcium-loaded states. Nat. Struct. Biol. 7:147-153.

Hegeman, C. E., and Grabau, E. A. 2001. A novel phytase with sequence similarity to purple acid phosphatases is expressed in cotyledons of germinating soybean seedlings. Plant Physiol. 126:1598-1608.

Jefferson, R. A., Kavanagh, T. A., and Bevan, M. W. 1987. Gus fusions: $\beta$-Glucuronidase as a sensitive and versatile gene fusion marker in higher plants. EMBO (Eur. Mol. Biol. Organ.) J. 6:3901-3907.

Jones T. A., Zou J. Y., Cowan, S. W., and Kjeldgaard, M. 1991. Improved methods for building protein models in electron density maps and the location of errors in these models. Acta Crystallogr. A 47:110-119

Kamdar, H. V., Kamoun, S., and Kado, C. I. 1993. Restoration of pathogenicity of avirulent Xanthomonas oryzae pv. oryzae and $X$. campestris pathovars by reciprocal complementation with the hrpXo and $h r p X c$ genes and identification of HrpX function by sequence analyses. J. Bacteriol. 175:2017-2025.

Kauffman, H. E., Reddy, A. P. K., Hsieh, S. P. Y., and Merca, S. D. 1973. An improved technique for evaluation of resistance of rice varieties to Xanthomonas oryzae. Plant Dis. Rep. 57:537-541.

Kelemu, S., and Leach, J. E. 1990. Cloning and characterization of an avirulence gene from Xanthomonas campestris pv. oryzae. Mol. Plant-
Microbe Interact. 3:59-65.

Kelley, L. A., MacCallum, R. M., and Sternberg, M. J. E. 2000. Enhanced genome annotation using structural profiles in the program 3D-PSSM. J. Mol. Biol. 299:499-520.

Kerovuo, J., Lauraeus, M., Nurminen, P., Kalkkinen N., and Apajalahti, J. 1998. Isolation, characterization, molecular gene cloning, and sequencing of a novel phytase from Bacillus subtilis. Appl. Environ. Microbiol. 64:2079-2085.

Laemmli, U. K. 1970. Cleavage of structural proteins during the assembly of the head of bacteriophage $\mathrm{T}_{4}$. Nature 227: 680-685.

Leach, J. E., White, F. F., Rhoads, M. L., and Leung, H. 1990. A repetitive DNA sequence differentiates Xanthomonas campestris pv. oryzae from other pathovars of $X$. campestris. Mol. Plant-Microbe Interact. 3:238-246

Lemtiri-Chlieh, F., MacRobbie, E. A. C., and Brearley, C. A. 2000. Inositol hexakisphosphate is a physiological signal regulating the $\mathrm{K}^{+}$-inward rectifying conductance in guard cells. Proc. Natl. Acad. Sci. U.S.A. 97:8687-8692.

Leyns, F., DeCleene, M., Swings, J. G., and Deley, J. 1984. The host range of the genus Xanthomonas. Bot. Rev. 50:308-356.

Miller, J. H. 1992. A Short Course in Bacterial Genetics: A Laboratory Manual for Escherichia coli and Related Bacteria. Cold Spring Harbor Laboratory Press, Cold Spring Harbor, NY, U.S.A.

Nielsen, H., Engelbrecht, J., Brunak, S., and von Heijne, G. 1997. Identification of prokaryotic and eukaryotic signal peptides and prediction of their cleavage sites. Protein Eng. 10:1-6.

Quandt, J., and Hynes M. F. 1993. Versatile suicide vectors which allow direct selection for gene replacement in gram-negative bacteria. Gene 127:15-21

Rajagopal, L. 1998. Genetics of Xanthomonas oryzae pathovar oryzae: Studies on pigment biosynthesis. Ph.D. thesis. Jawaharlal Nehru University, New Delhi, India.

Rajagopal, L., Dharmapuri, S., Sayeepriyadarshini, A. T., and Sonti, R. V. 1999. A genomic library of Xanthomonas oryzae pv. oryzae in the board host range mobilizing Escherichia coli strain S17-1. Int. Rice Res. Notes 24:20-21.

Rajeshwari, R., and Sonti, R. V. 2000. Stationary-phase variation due to transposition of novel insertion elements in Xanthomonas oryzae pv. oryzae. J. Bacteriol. 182:4797-4802.

Ray, S. K., Rajeshwari, R., Sharma, Y., and Sonti, R. V. 2002. A high molecular-weight outer membrane protein of Xanthomonas oryzae pv. oryzae exhibits similarity to non-fimbrial adhesins of animal pathogenic bacteria and is required for optimum virulence. Mol. Microbiol. 46:637-47.

Ray, S. K., Rajeshwari, R., and Sonti, R. V. 2000. Mutants of Xanthomonas oryzae pv. oryzae deficient in general secretory pathway are virulence deficient and unable to secrete xylanase. Mol. Plant-Microbe Interact. 13:394-401.

Reddy, N. R., Pierson, M. D., Sathe, S. K., and Salunkhe, D. K. 1989. Phytates in Legumes and Cereals. CRC Press, Boca Raton, FL, U.S.A.

Sambrook, J., Fritsch, E. F., and Maniatis, T. A. 1989. Molecular Cloning: A Laboratory Manual. 2nd ed. Cold Spring Harbor Laboratory Press, Cold Spring Harbor, NY, U.S.A.

Shen, Y., and Ronald, P. 2002. Molecular determinants of disease and resistance in interactions of Xanthomonas oryzae pv. oryzae and rice. Microbe. Infect. 4:1361-1367.

Shin, S., Ha, N., Oh, B., Oh, T., Oh, B. 2001. Enzyme mechanism and catalytic property of beta propeller phytase. Struct. Fold. Dis. 9: 851858

Simon, R., Preifer, U., and Pühler, A. 1983. A broad host range mobilization system for in vivo genetic engineering: Transposon mutagenesis in gram-negative bacteria. Biotechnol. 1:784-791.

Tang, J.-L., Feng, J.-X., Li, Q.-Q., Wen, H.-X., Zhou, D.-L., Wilson, T. J. G., Dow, J. M., Ma, Q.-S., and Daniels, M. J. 1996. Cloning and characterization of the rpfC gene of Xanthomonas oryzae pv. oryzae: Involvement in exopolysaccharide production and virulence to rice. Mol. Plant-Microbe Interact. 9:664-666.

Tsuchiya, K., Mew, T. W., and Wakimoto, S. 1982. Bacteriological and pathological characteristics of wild-type and induced mutants of Xanthomonas campestris pv. oryzae Phytopathology 72:43-46.

Wilson, K. J., Sessitch, A., Corbo, J. C., Giller, K. E., Akkermans, A. D. L., and Jefferson, R. A. 1995. $\beta$-Glucuronidase (GUS) transposons for ecological and genetic studies of rhizobia and other gram-negative bacteria. Microbiology 141:1691-1705.

Wyss, M., Pasamontes, L., Friedlein, A., Rémy, R., Tessier, M., Kronenberger, A., Middendorf, A., Lehmann, M., Schnoebelen, L., Röthlisberger, U., Kusznir, E., Wahl, G., Müller, F., Lahm, H.-W., Vogel, K., and van Loon, A. P. G. M. 1999. Biophysical characterization of fungal phytases (myo-inositol hexakisphosphate phosphohydrolase): Molecular size, glycosylation pattern, and engineering of 
proteolytic resistance. Appl. Environ. Microbiol. 65:359-366.

Yamasaki, Y., Murata, N., and Suwa, T. 1964. The effect of mutations for nutritional requirements on the pathogenicity of two pathogens of rice. Proc. Jpn. Acad. 40:226-231.

Yang, B., Zhu, W., Johnson, L. B., and White, F. F. 2000. The virulence factor AvrXa7 of Xanthomonas oryzae pv. oryzae is a type III secretion pathway-dependent nuclear-localized double-stranded DNA-binding protein. Proc. Natl. Acad. Sci. U.S.A. 97: 9807-9812.

Zhu, W., MaGbanua, M. M., and White, F. F. 2000. Identification of two novel hrp-associated genes in the hrp gene cluster of Xanthomonas oryzae pv. oryzae. J. Bacteriol. 182:1844-1853.

\section{AUTHOR-RECOMMENDED INTERNET RESOURCES}

3D-JIGSAW protein comparative modeling server: www.bmm.icnet.uk/ servers/3djigsaw

3D-PSSM protein fold recognition (threading) server: www.sbg.bio. ic. ac. uk/ 3dpssm/

Matrix Science Mascot search engine: www.matrixscience.com

National Center for Biotechnology Information website: www.ncbi.nlm. nih.gov

The University of California San Francisco ProteinProspector server: prospector.ucsf.edu 